\title{
New Comer -Teacher Adaptation and Leadership Succession in Higher Educational Institutions through Mentoring as an OS Practice
}

\author{
Jasmin $\mathbf{J}^{1}$, Dr. Kumari V K Shyni ${ }^{2}$ \\ ${ }^{1}$ Assistant Professor of Commerce, Mannaniya College of Arts \& Science, Pangode \\ ${ }^{2}$ Assistant Professor, Department of Commerce, Iqbal College, Peringammala
}

Corresponding Author: Jasmin J.

\begin{abstract}
New teachers have to cope with many issues in the initial phase which discourage them and persuade them to abandon their teaching profession. To transition themselves from a student- teacher to a professional-teacher, the initial years is the critical time of survival for the beginning teacher. It is during this initial phase of their career that they require extra support and caring supervision to adapt easily to their newly chosen roles. The current induction programmes utilised are not adequate enough to successfully evolve the transition of a newcomer teacher into the parent institution. This study utilises the theoretical framework of organisational socialisation and its literature to bridge the gap between teacher transformation and teacher retention, especially engaging the OS Practice of Mentoring. By examining the issues inherent in newcomer-teacher adaptation and the various dimensions of knowledge sharing transition process, from senior teachers (especially HOD) to the juniors in a departmental position, mentoring is found to be the most ideal and effective practice to solve burnout to a great extent, and to ensure successful retention of newcomer teachers.
\end{abstract}

Key Words: Organisational Socialisation, Mentoring, Teacher retention, Newcomer adaptation, transition process.

\section{INTRODUCTION}

Educational Profession is considered as one of the noblest of all professions. Higher education management hire young teachers with this intention. For the newly hired to adapt to the new surroundings and to equip them to facilitate the teaching, learning process, they need to undergo the socialisation process with ease. The administrators of higher education implement numerous strategies to facilitate socialisation at the organisational and departmental level. Yet the most effective of all socialisation practices is through mentoring. The long-term success of any institution depends on consistently having the right people in the right position especially as leading people.

Teachers are the most important part of the educational process and the main elements attached to education are the cultural transmission, social cohesion and justice, or human resource development, technology-based economies the higher is the priority that must be accorded to the teachers responsible for that education (OECD, 1989). Knowledge sharing from teachers to students is perceived as the main activity involved in education. Quoting Pisova (2018) "entering teaching profession is considered as the most determining stage in a teacher's professional life" because the first years of teaching can influence the length of career, effectiveness of work and job satisfaction... and teachers form their professional identity". Many previous studies in this area highlights the fact that the large number of beginning teachers leave the teaching profession within the first 
years of service and so educationalists everywhere are seeking to find methods, tools and practices to reduce this appalling trend (Buchanan, Prescott, Schuck, Aubusson, Burke, \& Louviere, 2013). The mentor-mentee relationship is the most beneficial strategy to enrich experience through a flow of information. However, there is a gap found on this mentoring process as most of the seniors are not broadminded enough to see their juniors grow and succeed.

The purpose of the paper is to examine the various dimensions of knowledge transition process especially through mentoring in the socialisation process of hiring of a new teacher and also the issues that hampers or hinders the flow of information and knowledge due to ineffective mentoring and to suggest various ways in which mentoring can be successfully implemented for organisational socialisation in a higher education institution. The study also identifies the benefits of mentoring system compared to other OS Practices.

\subsection{Objectives of the study} objectives.

The study aims at the following

1. To examine the various dimensions of knowledge transition process through mentoring system in the socialisation process of hiring of a new teacher in a higher educational institution.

2. To identify the issues that hampers the flow of information due to ineffective mentoring system.

3. To suggest various ways in which mentoring can be successfully implemented for organisational socialisation.

\subsection{METHODOLOGY}

The present study is descriptive in nature. Only Secondary data was used for the study. Secondary data was collected through published sources such as journals, website etc.

\section{DISCUSSION}

\subsection{Mentoring as an OS Practice.}

Mentoring is one of the numerous practices of organisational socialisation. Organisational socialisation is the process of adaptation to familiarise fresh employees (here teaching faculty) into their newly joined institution and to equip them with essential skills and acquaint themselves with the cultural values of the institution. The concept of mentoring has great significance in the realm of education. A major component of induction is mentoring, often the mentor assists with curriculum, guidance with classroom management, and general support and encouragement (Shakrani, 2008). Mentoring has a positive impact on novice teachers and their retention (Guarino, Santibanez, \& Dalely, 2006). This may reduce the costs associated with replacing teachers, and increase both student achievement and overall school performance (Smith \& Ingersoll, 2004). Academic mentors are not just faculty advisors but a person who fosters professional and personal relationships with mentee. In a broad perspective mentoring is taking a special interest over a long period of time, in helping another person so that the mentee grows and develop into a successful professional, through consistent guidance and support.

\subsection{REVIEW OF LITERATURE}

Allen, T. D., Eby, L. T., Chao, G. T., \& Bauer, T. N. (2017) found that socialisation and mentoring systems will be two important ways for maintaining and improving employee's human capital and suggested that human resources will create their own social networks of organisation complete with new socialisation and mentoring systems to enhance adjustment and carrier development.

Gannon, J. M. (2020), identifies mentoring as a flexible practice that support socialisation of newcomers and explores mentoring practices of HRM Executives to socialise managers in an International Industry through in-depth interviews. The 
results of the study highlight the comprehension mentoring can make require the high levels of mobility. The implications of the study warrant how mentoring experiences enhance international careers and how organisations can capitalise from mentoring interventions.

\subsection{Newcomer Teacher adaptation through Mentoring}

Characteristics of an effective mentoring relationship are mutual respect, trust, understanding and empathy. Good mentors share life experiences and wisdom, technical advertise by being good listeners, good observers and good problem solvers. A good mentor takes extra effort to foster a relationship by knowing, accepting and respecting the goals and interest of a mentee. Successful mentoring is needed for new teachers to survive their beginning stage teaching and develop their teaching competencies (Marble \& Raimondi, 2007).

Mentoring is building an intimate relationship between two individuals to support learning and experimentation, to facilitate individual development. A senior colleague can foster the professional success of the subordinate faculty. Mentoring connects people a builds relationship with help to achieve a goal and succeed. It empowers the inexperience by the support of the experienced senior. A good mentor provides opportunities to makes decisions, builds confidence and help them to achieve their goals. In an ideal mentor - mentee relationships the transmission of knowledge and experience happens naturally. A good mentor is enthusiastic to help and support others, respect others and enjoys his active role in facilitating others to achieve their goals.

\subsection{Leadership succession through Mentoring}

Mentoring is an effective OS Practice to ease Leadership succession or for successful replacement of a faculty head in a department. The development of future leaders is paramount for the success of any institution and it requires an environment of mutual respect and growth. Moulding the next successor while making them efficient is mandatory for the success of all the organisation or department. Effective succession involves more than just a replacement of a person, it also entails the transition of core values, key skills and experiences of a good leader to the successor. It requires a successful mentoring process involving the senior mentor and the mentee who is the next successor. It requires a successful mentoring process involving the senior mentor and the mentee who is the new successor. The experienced senior can help the newcomer to see the academic environment from a different perspective. They can empower the newcomer while helping them to have a broader perspective and enlightening them regarding some longterm consequences. The mentee gains the double benefit of engaging dual perspective.

Mentoring within the institution has a great role to play in making organizational socialization practices more effective. Senior teachers can transact organizational values and culture more successfully to the new faculty.

\subsection{Challenges inherent in Teacher transition process sans Mentoring}

At the beginning stage of teaching is very crucial, because each and every new teacher requires support to realize the needs and the importance of their work and to find the resources that will allow them to continue their work in a satisfying way (McCann \& Johannessen, 2004). The different categories of issues of beginning teachers as: relationships with students, parents, colleagues and supervisors; workload, time management, and fatigue; knowledge of subject and curriculum; evaluation and grading; authority and control; and appearance and identity (McCann, Johannessen, and Ricca 2005).

Without the effective mentoring system, leads to lack of knowledge transition and support from the seniors which creates confusion, error, and also 
creates problems and hinders the learning process. It creates stress, work anxiety, dissatisfaction among the newly recruited or the new successor. These issues can lead to frequent absenteeism among the newly recruited teachers and it will affect the quality teaching time and also students are at the losing end and the succession process will not be smooth. These will result in higher rate of turnover among novice teachers it will results in the failure of learning programme from the point of view of students. Frequent recruitment creates high expenses for the institution.

\subsection{Benefits of effective mentoring practice.}

Mentoring increases faculty retention and satisfaction it eventually benefits the student community as well as the administrators. Mentoring broadens professional networks by providing opportunity to develop a strong relationship between the colleagues and Sharing information and knowledge can reduce the burden of the newcomer.

The mentee gains: practical advises, encouragement and support; gets an opportunity to learn and benefit from the experiences of seniors; it empowers them to make independent decisions; it boost their academic confidence and personal skills; it helps them to devise strategies to deal with student related and academic issues from the beginning of their academic career.

Peer mentoring improves communication skills, cultural awareness, social confidences build the relationships among the faculty develops a greater connection and networking between colleagues. It helps to fill the gaps in knowledge and skills. It broadens their perspectives and encourages career development.

\section{CONCLUSION AND RECOMMENDATIONS}

A novice teacher is burdened with a host of responsibilities and asked to perform duties efficiently before they learn the ropes of the profession. It is important to, acquire the specific knowledge required, familiarise themselves with their responsibilities so as to integrate them to the institution in a successful manner. Newcomer teachers who enter unfamiliar academic settings fail miserably in executing their academic duties. This situation creates lack of interest in the students' unmet expectations of the organisation and eventually leads to work anxiety, job dissatisfaction and even untimely leaving the job. Through mentoring which is a continuous process an experienced mentor can facilitate to adapt them to the organisational expectations by making the beginners experience meaningful and fruitful. The attributes and experience of the mentor teacher transmits in a beneficent manner to the mentee teacher, empowering them immensely. The mentoring practices adopted by each institution should be more flexible and responsive to the needs of the mentee teacher and the requirements of the institution. It is believed that the old are wise and the young are intelligent. The wisdom and the practical knowledge of the senior colleague can enlighten the intelligence of the young teacher to invent innovative practices to make learning more meaningful and interesting. Hence, every organisation should ensure an effective mentoring process before a succession or a replacement.

Any institution may encounter a situation where they require a sudden replacement. A senior should identify and train backup people for the replacement position much before planning is change. This study suggests to maintain mentoring system by each institution, entrusting senior teachers as mentors and a bunch of young teachers as mentees so that the transition process becomes smoother if an eventuality arises. Each institution can form a mentoring cell for the purpose along with student mentoring system. Peer mentoring can also be encouraged in the absence of adequate number of senior faculties. This mentoring system will also enhance teacher 
Jasmin J et. al. New comer -teacher adaptation and leadership succession in higher educational institutions through mentoring as an OS practice.

networking and builds trust and relationships. This bonding between the teaching fraternity will further strengthen the institution to provide quality education.

\section{Acknowledgement: None}

\section{Conflict of Interest: None}

\section{Source of Funding: None}

\section{REFERENCES}

1. Allen, T. D., Eby, L. T., Chao, G. T., \& Bauer, T. N. (2017). Taking stock of two relational aspects of ORGANIZATIONAL Life: Tracing the history and shaping the future of socialization and mentoring research. Journal of Applied Psychology, 102(3), 324-337.

2. Buchanan, J., Prescott, A., Schuck, S., Aubusson, P., Burke, P., \& Louviere, J. (2013). Teacher retention and attrition: Views of early career teachers. Australian Journal of Teacher Education, 38(3).

3. Gannon, J. M. (2020). Mobility and mentoring: Supporting socialisation in international service firms. International Journal of Evidence Based Coaching and Mentoring, 18(1), 3-19.

4. Guarino, C. M, Santibanez, L., \& Daley, G. A. (2006). Teacher recruitment and retention: A review of the recent empirical literature. Review of Educational Research, 76(2), pp.173-208.

5. Marable, M. A., \& Raimondi, S. L. (2007). Teachers' perceptions of what was most (and Least) supportive during their first year of teaching. Mentoring \& Tutoring: Partnership in Learning, 15(1), 25-37.

6. McCann, T. M., \& Johannessen, L. R. (2004). Why do new teachers cry? The Clearing House: A Journal of Educational Strategies, Issues and Ideas, 77(4), 138-145.

7. McCann, T.M., Johannessen, L.R., \& Ricca, B. (2005). Responding to new: An in-depth study of novice high school teachers suggests key strategies to address their most pressing challenges. Educational Leadership, May, 30-34.

8. Paula, L., \& Grinnfelde, A. (2018). The role of mentoring in professional socialization of novice teachers. Problems of Education in the 21st Century, 76(3), 364-379.

9. Píšová, M. (2018). Teacher professional socialisation: Objective determinants. ORBIS SCHOLAE, 7(2), 67-80.

10. Shakrani, S. (2008). Teacher turnover: Costly crisis, solvable problem. (ERIC Document Reproduction Service No. ED502130).

11. Smith, T. M., \& Ingersoll, R. M. (2004). What are the effects of induction and mentoring on beginning teacher turnover? American Educational Research Journal, 41(3), pp.681-714.

How to cite this article: Jasmin J, Kumari V K Shyni. New comer-teacher adaptation and leadership succession in higher educational institutions through mentoring as an OS practice. International Journal of Research and Review. 2021; 8(12): 70-74. DOI: https://doi.org/10.52403/ijrr.20211210 